\title{
Gentian lipid transfer protein homolog with antimicrobial properties confers resistance to Botrytis cinerea in transgenic tobacco
}

\author{
Akinori Kiba ${ }^{1, *}$, Takashi Nakatsuka ${ }^{2}$, Saburo Yamamura ${ }^{2}$, Masahiro Nishihara ${ }^{2}$ \\ ${ }^{1}$ Laboratory of Plant Pathology and Biotechnology, Faculty of Agriculture, Kochi University, Nankoku, Kouchi 783-8502, \\ Japan; ${ }^{2}$ Iwate Biotechnology Research Center, Kitakami, Iwate 024-0003, Japan \\ *E-mail: akiba@kochi-u.ac.jp Tel: +81-88-864-5196 Fax: +81-88-864-5218
}

Received August 3, 2011; accepted November 14, 2011 (Edited by Y. Watanabe)

\begin{abstract}
An antifungal protein fraction against Botrytis cinerea was purified from the leaves of Gentiana triflora. Polypeptides with molecular weight ca. $8.0 \mathrm{~K}(8.0 \mathrm{KP})$ and $7.0 \mathrm{~K}(7.0 \mathrm{KP})$ were detected by Tricine-SDS PAGE under reducing conditions. The deduced amino acid sequence of $8.0 \mathrm{KP}$ cDNA showed amino acid identities with lipid transfer proteins from Apium graveolens (32.4\%), Lycopersicon pennellii (31.5\%), L. esculentum (31.5\%), Nicotiana tabacum (30.7\%), non-specific lipid transfer protein from L. esculentum (28.0\%), and an unknown protein from Prosopis juliflora (30.7\%) (GtLTP1). The deduced amino acid sequence of 7.0 KP showed amino acid identities with putative lipid transfer proteins from Arabidopsis thaliana (26.3\% and 22.9\%), Gossypium hirsutum (21.0\%), Tamarix hispida (19.5\%), Populus trichocarpa (15.9\%) and an unknown protein from Vitis vinifera (17.2\%) (GtLTP2). Both GtLTP1 and GtLTP2 were present as a multigene family in the genome and were strongly expressed in the roots and stems. Overexpression of GtLTP1 in tobacco plants improved tolerance against B. cinerea, demonstrating that GtLTP1 is a useful molecular tool for genetic engineering of disease-resistant plants.
\end{abstract}

Key words: $\quad$ Antifungal protein, Gentiana triflora, lipid transfer protein, transgenic tobacco.

Plants are endowed with a wide variety of defense mechanisms that protect them from attack by pathogenic microorganisms. Active defense mechanisms include hypersensitive cell death (Govrin and Levine 2000), production of phytoalexins (Kuc et al. 1972), expression of pathogenesis-related proteins (Mauch and Staehelin 1989), oxidative burst (Baker and Orlandi 1995), crosslinking of cell wall glycoproteins (Bradly et al. 1992, Brisson et al.1994) and lignification (Vance et al. 1980). Many plant proteins with antimicrobial activity have also been identified. These proteins include chitin-binding proteins (van den Bergh et al. 2004), thionines (LoezaAngeles et al. 2008), PR-4 type protein (Friedrich et al. 1991), lipid-transfer proteins (Marison et al. 2007), plant defensines (Thomma et al. 2002), PR-1 type proteins (Kiba et al. 2007), win type proteins (Caruso et al. 1996), hevein-like protein (Kiba et al. 2003), and 7S globulin proteins (Marcus et al. 1999). Fourteen families of pathogenesis-related $(\mathrm{PR})$ protein were also recognized and classified (van Loon and van Strien 1990).Some antimicrobial proteins are induced by different stress stimuli, such as infection by viruses, bacteria, and fungi or treatment with salicylic acid or jasmonic acid (Linthorst 1991). These proteins may have an important role in the protection of plants against microbial infection.

Ectopic expression of antimicrobial protein genes as a result of genetic transformation can confer enhanced disease resistance in crop plants (Evans and Greenland 1998). The overexpression of chitinase (Broglie et al. 1991), osmotin-like proteins (Zhu et al. 1996), thionin (Epple et al. 1997), non-specific lipid transfer proteins (Molina and García-Olmedo 1997), and small cysteinerich plant defensins (Bi et al. 1999) enhance pathogenic fungi and bacterial resistance in various plant species. However, the expression of antimicrobial protein genes in transgenic plants is not always effective in conferring resistance and often only partial resistance is obtained

Abbreviations: bar, phosphinothricin acetyltransferase; CaMV, cauliflower mosaic virus; DET, dithioerythreitol; DIG, digoxigenin; LTP, lipid transfer protein; nsLTP, non specific lipid transfer protein; RACE, rapid amplification of cDNA ends; RT-PCR, reverse transcription polymerase chain reaction; SDS, sodium dodecyl sulfate; TFA, trifluoroacetic acid.

The nucleotide sequence reported in this paper has been submitted to DDBJ, EMBL and Gene Bank under accession number AB638714 (GtLTP1) and AB638715 (GtLTP2).

This article can be found at http://www.jspcmb.jp/

Published online February 20, 2012 


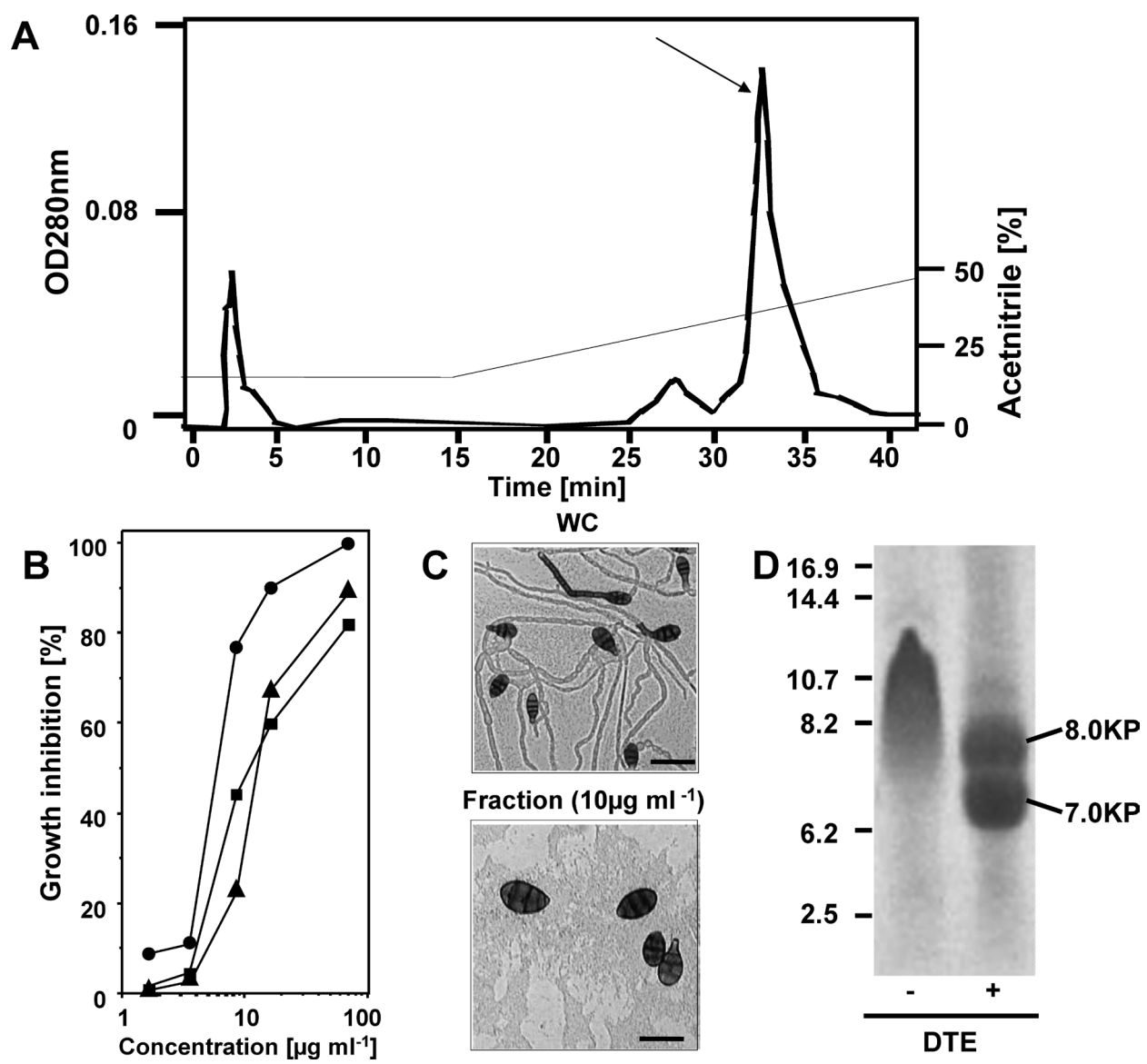

Figure 1. Purification of antimicrobial protein. (A) Protein fractions extracted from gentian leaves and separated by a reverse-phase column as described in the text. The arrow indicates the peak corresponding to antifungal fraction. (B) Growth inhibition of the fungi Alternaria alternata ( $\mathbf{\Delta}$ ), Botrytis cinerea (-) and Fusarium solani ( $\mathbf{\square})$ at different concentration of antifungal fraction. (C) Microscopic observations of Alternaria alternata growth $24 \mathrm{~h}$ after the start of culture in the absence (WC) or presence of antimicrobial fraction at a concentration of $10 \mu \mathrm{g} \mathrm{ml}{ }^{-1}$. Bar indicates $100 \mu \mathrm{m}$. (D) Tricine-SDS-PAGE analysis of antimicrobial fraction in the absence $(-)$ or presence $(+)$ of dithioerythreitol (DET). The molecular masses $(\mathrm{kDa})$ of the marker proteins are indicated on the left.

(Evans and Greenland 1998). Therefore, the development of novel proteins (substances) that show high antimicrobial activity is one of the solutions to overcome this problem.

Gentian plants are often used for medicinal purposes and are a suitable source for isolation of novel antimicrobial agents. However, we are the only group to report on antimicrobial proteins in gentian plants (Kiba et al. 2005). In this paper, we isolate an antimicrobial protein and clone its corresponding cDNA from a gentian plant. We successfully isolated $8.0 \mathrm{kDa}$ and $7.0 \mathrm{kDa}$ lipid transfer protein (LTP), which designated as GtLTP1 and 2, respectively. We also analyzed the antimicrobial function of GtLTP1 and create diseaseresistant, stably transformed tobacco plants.

Gentiana triflora cv. Yahaba Y514-8-38 was provided by the Iwate Agricultural Research Center and maintained in a greenhouse. Antifungal protein was purified using the method described by Kiba et al. (2005), with a slight modification. One hundred grams of mature gentian leaves was homogenized in extraction buffer containing $10 \mathrm{mM} \mathrm{NaH} \mathrm{PO}_{4}, 15 \mathrm{mM}$ $\mathrm{Na}_{2} \mathrm{HPO}_{4}, 100 \mathrm{mM} \mathrm{KCl}, 2 \mathrm{mM}$ EDTA, $1.5 \%$ (w/v) polyvinylpolypyrrolidone, $2 \mathrm{mM}$ thiourea and $1 \mathrm{mM}$ phenylmethylsulfonylfluoride with a homogenizer (ULTRA-TURRAX T25, Janke \& Kunkel, GmbH \& Co., IKA-Labortechnik, Germany). The extract was then centrifuged for $30 \mathrm{~min}$ at $32000 \times \mathbf{g}$ and the supernatant was extensively dialyzed against deionized water using a dialyzed membrane (Spectro-pore; cut-off $1000 \mathrm{Da}$ ). The dialyzed solution was adjusted to $0.1 \%$ trifluoroacetic acid (TFA) and subjected to reverse phase high performance liquid chromatography on TSKgel phenyl5PW RP (Tosoh, Tokyo, Japan) in equilibrium with $0.1 \%$ TFA. Proteins were eluted with a linear gradient of $0-50 \%$ solvent B $(0.1 \%$ TFA in $100 \%$ acetonitrile) in solvent A (0.1\% TFA in deionized water) at a flow rate of $1 \mathrm{ml} / \mathrm{min}$ for $200 \mathrm{~min}$ and collected every $1 \mathrm{~min}$. Fractions were assayed for growth inhibition against the fungal pathogen, Botrytis cinerea, as described below. Protein concentrations were determined by the method of Bradford (1976) with bovine serum albumin as a 
Table 1. Antifungal activity of antimicrobial fraction in the presence of different cations.

\begin{tabular}{ccccccc}
\hline & \multicolumn{5}{c}{ Relative inhibition of fungal germination (\%) } \\
\hline \multirow{2}{*}{ Medium A } & Medium B & \multicolumn{5}{c}{ Medium A supplemented with } \\
\cline { 3 - 7 } & & $50 \mathrm{mM} \mathrm{K}^{+}$ & $50 \mathrm{mMNa}^{+}$ & $50 \mathrm{mM} \mathrm{NH}_{4}^{+}$ & $50 \mathrm{mM} \mathrm{Mg}^{2+}$ & $50 \mathrm{mM} \mathrm{Ca}^{2+}$ \\
\hline 66.0 & 72.9 & 63.1 & 60.1 & 84.8 & 86.3 & 64.5 \\
\hline
\end{tabular}

Medium A: Synthetic growth medium. Medium B: medium A supplemented with $1 \mathrm{mM} \mathrm{CaCl}$ and $50 \mathrm{mM} \mathrm{KCl}$. Data was represented germination rate without antimicrobial fraction as 100 .

standard. Tricine-SDS-PAGE was performed and stained with Coomassie brilliant blue G250 (Shagger and von Jagow 1987).

B. cinerea strain $\mathrm{S} 1$ and Fusarium solani were grown on potato dextrose agar at $25^{\circ} \mathrm{C}$ for two weeks under white fluorescent lighting. Alternaria alternata apple pathotype were grown at $25^{\circ} \mathrm{C}$ for two weeks under blue fluorescent lighting on potato dextrose agar or oatmeal agar (Kiba et al. 2003). Conidia of the fungal pathogen were suspended and washed with deionized water, and adjusted to $1 \times 10^{8}$ spores $\mathrm{ml}^{-1}$. Antimicrobial activity was measured by microspectrophotometry under the conditions described by Cammue et al. (1992). Antifungal activity was measured at $25^{\circ} \mathrm{C}$ over a 24 -h period in reaction solution consisting of $10 \mu \mathrm{l}$ of test solution and $90 \mu \mathrm{l}$ of fungal spore suspension $\left(1 \times 10^{5}\right.$ spores $\left.\mathrm{ml}^{-1}\right)$. Fungal spores were suspended in a synthetic growth medium containing $2.5 \mathrm{mM}$ $\mathrm{K}_{2} \mathrm{HPO}_{4}, 50 \mu \mathrm{M} \mathrm{MgSO}, 50 \mu \mathrm{M} \mathrm{CaCl}, 5 \mu \mathrm{M} \mathrm{FeSO}$, $0.1 \mu \mathrm{M} \mathrm{CuSO}_{4}, 2 \mu \mathrm{M} \mathrm{Na}_{2} \mathrm{MoO}_{4}, 0.5 \mu \mathrm{M} \mathrm{H}_{3} \mathrm{BO}_{3}, 0.1 \mu \mathrm{M}$ $\mathrm{KI}, 0.5 \mu \mathrm{M} \mathrm{ZnSO}_{4}, 0.1 \mu \mathrm{M} \mathrm{MnSO}_{4}, 10 \mathrm{gl}^{-1}$ glucose, $1 \mathrm{gl}^{-1}$ asparagine, $20 \mathrm{mg} \mathrm{ml}^{-1}$ methionine, $2 \mathrm{mgl}^{-1}$ myoinositol, $0.2 \mathrm{mgl}^{-1}$ biotin, $1 \mathrm{mgl}^{-1}$ thiamine- $\mathrm{HCl}$, and $0.2 \mathrm{mgl}^{-1}$ pyridoxine- $\mathrm{HCl}$.

Figure 1A shows the separation pattern of proteins extracted from $G$. triflora leaves. The fraction indicated by an arrow inhibited growth of the fungal pathogen $B$. cinerea. The purified antimicrobial fraction inhibited the growth of the phytopathogenic fungi, A. alternata, $B$. cinerea and $F$. solani in a dose-dependent manner (Figure 1B). Microscopic observations showed that the purified antimicrobial fraction inhibited both spore germination and the growth of A. alternata germinating hyphae (Figure 1C). The antifungal activity of the purified antimicrobial fraction was scarcely affected by the presence of cations (Table 1). Analysis of this fraction using tricine-SDS-PAGE showed a single major band corresponding approximately to $11.0 \mathrm{kDa}$ under non-reducing conditions. In contrast, the fraction was divided into two polypeptides, with molecular weight approximately to $8.0 \mathrm{kDa}(8.0 \mathrm{KP})$ and $7.0 \mathrm{kDa}(7.0 \mathrm{KP})$, under reducing conditions (Figure 1D).

The purified proteins were separated by Tricine-SDSPAGE and electroblotted on a polyvinylidene difluoride membrane. Proteins were visualized by staining with Coomassie brilliant blue G250. Bands of interest were cut out and sequenced using a protein sequencer (HP G1005A, TaKaRa-Bio, Shiga, Japan).

Total RNA was extracted from gentian leaves using a fast-green RNA purification kit (BIO101, CA, USA). Based on the $\mathrm{N}$-terminal amino acid sequences of 8.0 KP and 7.0 KP, the following primers were designed for RT-PCR: 5' -YTIACITGYGGIGCIGTIAC-3' and 5'-GCIGCIGTITGYAAYYTIGGIGC-3'. RT-PCR was performed with a High Fidelity RNA PCR kit with an oligodT $_{(16)}$ primer as the antisense primer (TaKaRa-Bio). $5^{\prime}$-RACE was performed to isolate the complete cDNA of $8.0 \mathrm{KP}$ and 7.0 KP. Based on the internal nucleotide sequences of the RT-PCR product, we designed 5' -TGTTGCAACACATACTACTACATTTATAAA-3' for $8.0 \mathrm{KP}$ and $5^{\prime}$-GGGGTATTTCCTAAGATACCC-3' for 7.0 KP. Using the nucleotide sequences of the RTPCR and $5^{\prime}$-RACE products, the specific primers, 5' - ATAT TCATAGTCATCAT TCACT TACTC-3' and 5'-GCAAAACATACATTCGTTTTC-3' were synthesized to generate the full-length cDNA of $8.0 \mathrm{KP}$ and 7.0KP, respectively. The full-length cDNAs were cloned into a pCR2.1 vector (Invitrogen, California, USA). DNA sequencing was performed using a Big Dye Terminator cycle sequencing kit (Applied Biosystems, Tokyo, Japan) and an Applied Biosystems 377 Automated Sequencer. Sequence alignments and analyses were performed using DNASIS (version 3.6; Hitachi, Tokyo, Japan) and the BLAST network service from the National Center for Biotechnology Information (NCBI) (Altschul et al. 1990).

$\mathrm{N}$-terminal amino acid sequences of $8.0 \mathrm{KP}$ and $7.0 \mathrm{KP}$ up to the 12 th residue were determined as LTCGAVTSAVGP and AAVCNLGALQRP, respectively (Figure 2A). The $600 \mathrm{bp}$ cDNA corresponding to $8.0 \mathrm{KP}$ obtained by PCR contained an open reading frame (ORF) encoding a polypeptide 115 amino acids in length, which included the same amino acid sequence as the N-terminus, as determined by Edman digestion. A search of the protein database using NCBI's BLASTP program showed amino acid identities with LTPs from Apium graveolens (32.4\%), Lycopersicon pennellii (31.5\%), L. esculentum (31.5\%), Nicotiana tabacum (30.7\%), a non specific LTP from L. esculentum (28.0\%), and an unknown protein from Prosopis juliflora (30.7\%). The $660 \mathrm{bp}$ long cDNA corresponding to $7.0 \mathrm{KP}$ contained an ORF encoding for a polypeptide 95 amino acids in 


\section{A $\quad$ GtLTP1 (8.0KP)}

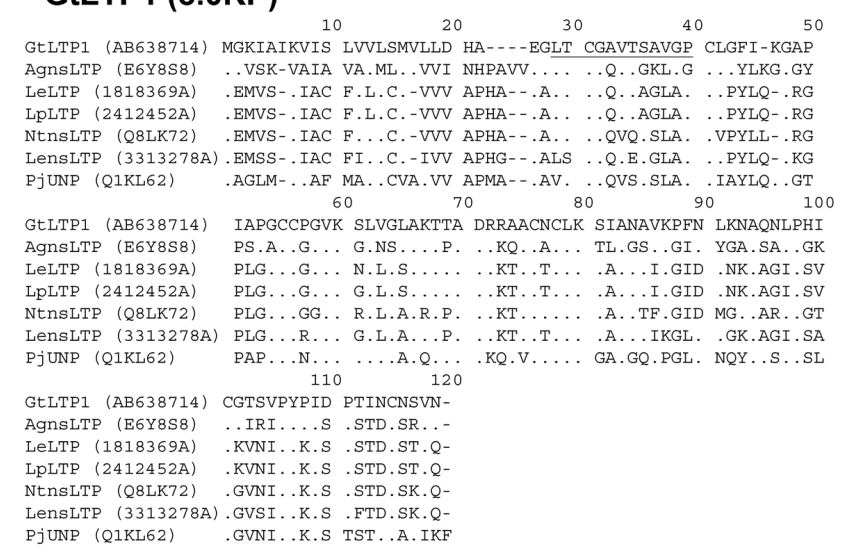

\section{GtLTP2 (7.0KP)}
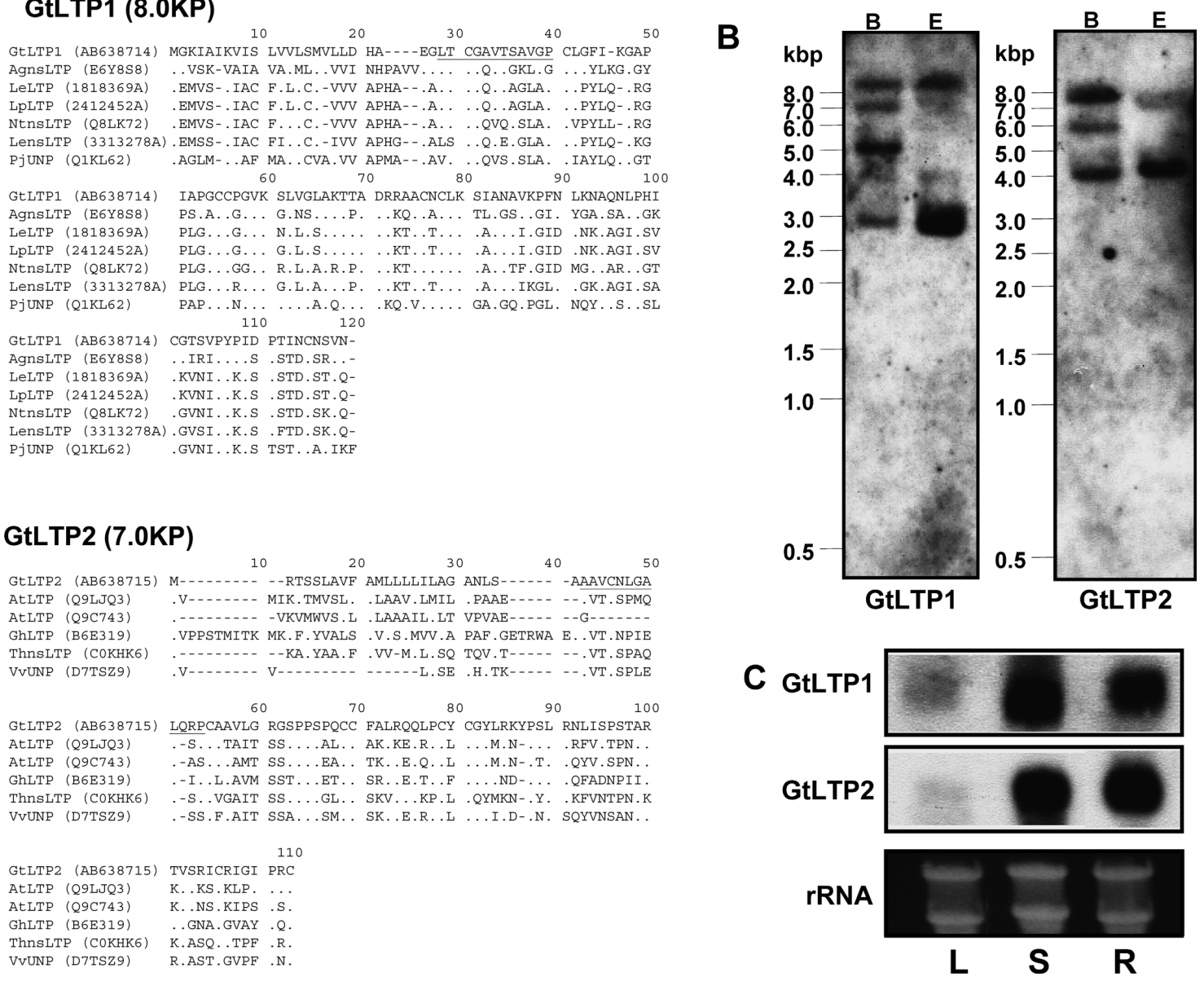

Figure 2. Characterization of antimicrobial proteins. (A) Alignment of $8.0 \mathrm{KP}$ antimicrobial protein (GtLTP1; AB638714) and lipid transfer proteins from Apium graveolens (AdnsLTP; E6Y8S8), Lycopersicon esculentum (LeLTP; 1818369A), L. pennellii (LpLTP; 2412452A), Nicotiana tabacum (NtLTP; Q8LK72), non-specific lipid transfer protein from L. esculentum (LensLTP; 3313278A), and an unknown protein from Prosopis juliflora (PjUNP; Q1KL62). Alignment of 7.0 KP antimicrobial protein (GtLTP2; AB638715) and putative lipid transfer proteins from Arabidopsis thaliana (AtLTP; Q9LJQ3 and Q9C743), Gossypium hirsutum (GhLTP; B6E319), Tamarix hispida (ThLTP; C0KHK6), and an unknown protein from Vitis vinifera (VvUNP; D7TSZ9). (B) Southern blot analysis of GtLTP1 and GtLTP2. Genomic DNA (10 $\mu \mathrm{g})$ was digested with BamHI and EcoRI. The DNA size markers are indicated on the left. (C) Expression analysis of GtLTP1 and GtLTP2 genes. Total RNA was isolated from leaf, stem, and root samples. Staining of rRNA with ethidium bromide was conducted as a control for equal loading of RNA.

length, which included the same amino acid sequence as the $\mathrm{N}$-terminus. The sequence showed amino acid identities with putative LTPs from Arabidopsis thaliana (26.3\% and 22.9\%), Gossypium hirsutum (21.0\%), Tamarix hispida (19.5\%), Populus trichocarpa (15.9\%), and an unknown protein from Vitis vinifera (17.2\%). Plant LTPs are a homogeneous class of small $(9-10 \mathrm{kDa})$, abundant, ubiquitous, and mostly basic proteins containing eight cysteine residues with four conserved disulfide bridges. LTPs are ubiquitous in the plant kingdom including rice (Lee et al. 1998), maize (Shin et al. 1995), and wheat (Simorre et al. 1991). LTPs which can enhance intermembrane transfer without lipid specificity are termed non-specific LTPs (nsLTPs), which form a multigenic family of proteins that can be subclassified as nsLTP1 and nssLTP2 (Douliez et al. 2000). Structural analysis with BLAST suggested that $8.0 \mathrm{KP}$ and $7.0 \mathrm{KP}$ were classified as part of the nsLTP1 family and nsLTP2 family, respectively. We therefore designated 8.0 KP and 7.0 KP as Gentiana triflora Lipid transfer protein 1 (GtLTP1) and Gentiana triflora Lipid transfer protein 2 (GtLTP2), respectively.

Total DNAs $(10 \mu \mathrm{g})$ extracted from gentian leaves were digested with BamHI and EcoRI restriction enzymes that did not cut the GtLTP1-cDNA and GtLTP2-cDNA. Fragments were separated on a $1 \%$ agarose gel and transferred to a Hybond $\mathrm{N}+$ membrane. Hybridization was performed with a digoxigenin (DIG)-labeled cDNA probes, and the membrane was washed with $2 \times$ SSC with $0.1 \%$ SDS at $55^{\circ} \mathrm{C}$ and $0.1 \times$ SSC with $0.1 \%$ SDS at $65^{\circ} \mathrm{C}$. Detection was performed using an alkaline phosphataseconjugated anti-DIG antibody (Roche) and CSPD (Boehringer Mannheim) according to the supplier's instructions. Total RNA was isolated from leaves, roots, and stems from gentian plants as described above. RNA $(5 \mu \mathrm{g})$ was separated on a $1.0 \%$ agarose gel under 
A

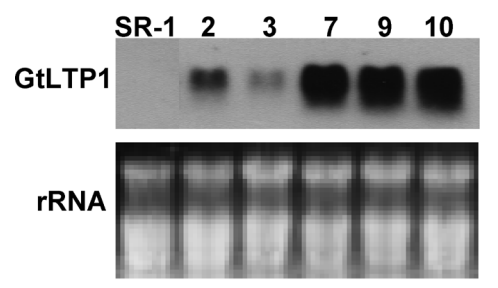

B

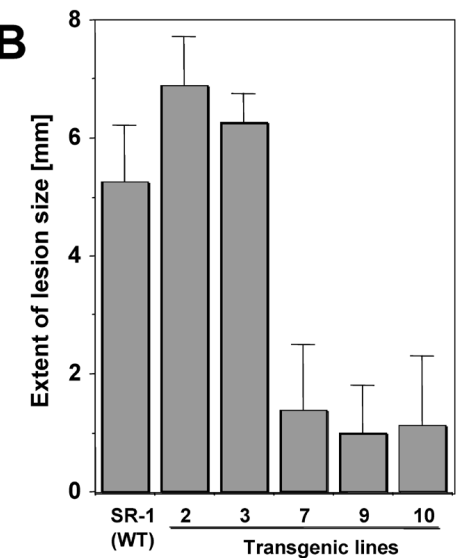

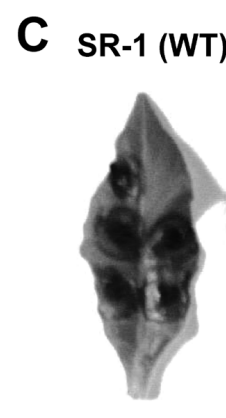
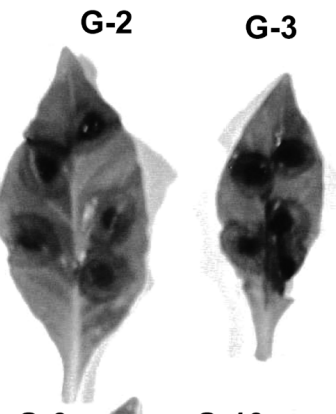

G-7
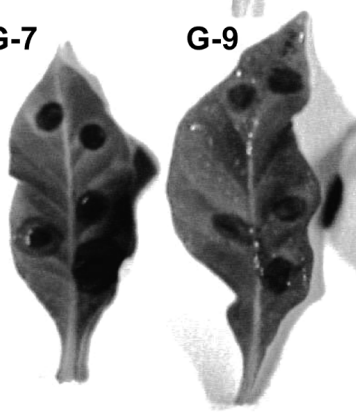

G-10

Figure 3. Expression of GtLTP1 in transgenic tobacco plants. (A) Expression of GtLTP1 in transgenic tobacco plants. Total RNA was isolated from fully expanded tobacco leaves of untransformed control (SR-1) or $\mathrm{T}_{2}$ GtLTP1-transformed plants (nos. 2, 3, 7, 9, 10). Equal loading of RNA was verified by visualizing rRNA in gel stained with ethidium bromide (bottom). (B) Enhancement of disease resistance against the fungal pathogen, Botrytis cinerea, in transgenic tobacco. Lesion extension by B. cinerea measured 5 days after inoculation. Each value represents the mean with standard deviation (SD) of results from triplicate experiments. (C) The extent of lesion sizes caused by the fungus 5 days after inoculation in untransformed control (SR-1) and homozygous $\mathrm{T}_{2}$ transgenic plants.

denaturing conditions and blotted onto a Hybond $\mathrm{N}+$ membrane. The blot was hybridized with DIG-labeled cDNA probes as described above.

Southern blot analysis showed multiple copies of the GtLTP1 and GtLTP2 genes per genome (Figure 2B). To further characterize GtLTP1 and GtLTP2, the organ expression pattern was determined by northern blot analysis. Both GtLTP1 and GtLTP2 mRNAs were abundant in the stems and roots, with less expression in the leaves (Figure 2C).

LTPs function as a carrier of the acyl monomer, which is an essential building block in cutin biosynthesis and strengthening the cell wall through the secretion or deposition of cutin (Kader 1996). LTPs show TED4/ p48h-10-like functions in plant vascular development (Endo et al. 2001). In addition, LTPs are also members of the ubiquitous class of antimicrobial peptides, with some LTPs able to inhibit the growth of fungal and bacterial pathogens in vitro (Marison et al. 2007; Molina et al. 1997; Terras et al. 1993). Both GtLTP1 and GtLTP2 showed antifungal activity and are part of the non-specific lipid transfer protein family, so we focused on GtLTP1 to test the possibility of creating disease-resistant plants. We therefore created GtLTP1overexpressing transgenic tobacco plants by cloning the ORF of GtLTP1 between the CaMV35S promoter and the nopaline synthase terminator of pBIS221S, which was derived from pBI221 (Clontech) using BamHI and SalI sites. The pBIS221SGtLTP1 was cut with SseI and cloned into a binary vector, $\mathrm{pEKB}$, which was generated by exchanging the expression cassette of hygromycin phosphotransferase ( $h p h)$ (pEKH) (Kiba et al. 2005) with that of phosphinothricin acetyltransferase (bar), resulting in pEKB-GtLTP1. The construct was transformed into Agrobacterium tumefaciens EHA105 by electroporation. Tobacco plants (Nicotiana tabacum cv. SR-1) were transformed via an A. tumefaciens-mediated leaf disc procedure (Horsch et al. 1985) and selected using $5 \mu \mathrm{g}$ $\mathrm{ml}^{-1}$ of bialaphos (Meiji Seika, Tokyo, Japan) as the selection reagent. After rooting and acclimatization, the regenerated plants were grown in a greenhouse to set seeds. Spores of B. cinerea were resuspended in potato glucose liquid medium and adjusted to $1 \times 10^{8}$ spores $\mathrm{ml}^{-1}$. Filter paper $\left(8 \mathrm{~mm}^{2}\right)$ dipped in the spore suspension was then placed onto detached fully expanded leaves from 4- to 5-week-old transgenic (homozygous $\mathrm{T}_{2}$ ) and wild-type tobacco plants. They were then kept in a moistened box under dim light conditions. The extent of lesion sizes was measured 5 days after inoculation (Kiba et al. 2005).

Expression of foreign genes was determined by northern blot analysis using a GtLTP1 cDNA probe, 
and 5 transgenic lines, including expressed at high (line $7,9,10$ ), intermediate (line 2), and low levels (line 3) were selected (Figure $3 \mathrm{~A}$ ). We could not observe any phenotypic changes in the transgenic plants (data not shown). Typical lesions were observed and the extent of lesion sizes reached about $5 \mathrm{~mm}$ in wild-type tobacco plants 5 days-after inoculation of $B$. cinerea spores. In contrast, lesion expansion was significantly reduced in the three transgenic lines (line 7,9 and 10) that strongly expressed GtLTP1. Transgenic lines that showed moderate or weak GtLTP1 expression did not show reduction of the extent of lesion sizes against $B$. cinerea (lines 2 and 3), suggesting that overexpression of GtLTP1 suppresses disease development of $B$. cinerea and that GtLTP1 has an antifungal activity.

The antifungal activity of cysteine-rich antimicrobial proteins, such as thionine and defensine, is reduced by cations (Cammue et al. 1992; Florack et al. 1994; Terras et al. 1993; Terras et al. 1995). These antifungal peptides might interact with fungal membrane lipids to form membrane pores and cause leakage of cytoplasmic materials (van Loon and van Strien 1990). However, the antifungal activity of purified antimicrobial fractions composed of both $8.0 \mathrm{KP}$ and 7.0 KP was scarcely affected by the presence of cations (Table 1), suggesting a different mechanism of antifungal activity than defensin, thionin, and hevein-like protein. Based on the P-Sort program, the probable subcellular localization of GtLTP1 is outside the cell, including the cell wall. Certain LTPs with fungicidal activity are localized in apoplastic areas (Garcia-Olmedo et al. 1995), and GtLTP1 may show similar localization.

LTPs are involved in plant-pathogen interactions. Jung et al. (2003) reported that the transcripts of three LTPs accumulated in the leaf, stem, and fruit tissues of pepper plants following infection with Xanthomonas campestris pv. vesicatoria, Phytophthora capsici, and Colletotricum gloeosporioides, and that they were strongly induced in systemic leaves infected by pathogenic or non-pathogenic bacteria. Moreover, LTP expression increased following inoculation of the pepper plants with Tobacco mosaic virus (Park et al. 2002). In addition, nsLTP1s share some structural and non-specific lipid binding properties with elicitins from Phytophthora species, which induces a hypersensitive response. Both nsLTP1 and elicitin are commonly bound to elicitin receptors on the plasma membrane, suggesting that LTP1 can modulate intracellular signal transduction (Blein et al. 2002; Buhot et al. 2001). LTP can also play a role in long-distance systemic signaling in plants (Sarowar et al. 2009). These results indicate that plant LTPs can function both in direct plant defense as antimicrobial agents and in regulation of plant immune responses.

Transgenic plants overexpressing GtLTP1 acquired disease resistance. We speculate that GtLTP1 shows direct toxicity to the microbial pathogen and/or regulates plant immune responses. In conclusion, the GtLTP1 gene might have potential for genetic engineering of enhanced disease resistance in plants. GtLTP2 might also contribute to antifungal activity and the regulation of plant immune responses, although further study is needed to verify this hypothesis.

\section{Acknowledgements}

We are grateful to Ms. Kaori Oomiya and Shizuka Nagasaka for technical assistance during this experiment. This work was supported by Iwate prefecture government.

\section{References}

Altschul SF, Gish W, Miller W, Myers EW, Lipman DJ (1990) Basic local alignment search tool. J Mol Biol 215: 403-410

Baker CJ, Orlandi EW (1995) Active oxygen in plant pathogenesis. Annu Rev Phytopathol 33: 299-321

Bi YM, Cammue BPA, Goodwin PH, KrishnaRaj S, Saxena PK (1999) Resistance to Botrytis cinerea in scented geranium transformed with a gene encoding the antimicrobial protein AceAMP1. Plant Cell Rep 18: 835-840

Blein JP, Coutos-Thévenot PC, Marion D, Ponchet M (2002) From elicitins to lipid-transfer proteins: a new insight in cell signalling involved in plant defence mechanisms. Trends Plant Sci 7: 293-296

Bradford MM (1976) A rapid and sensitive method for the quantitation of microgram quantities of protein utilizing the principle of protein-dye binding. Anal Biochem 72: 248-254

Bradley DJ, Kjellbom P, Lamb CJ (1992) Elicitor- and woundinduced oxidative cross-linking of a proline-rich plant cell wall protein: a novel, rapid defense response. Cell 70: 21-30

Brisson LF, Tenhaken R, Lamb CJ (1994) Function of oxidative cross-linking of cell wall structural proteins in plant disease resistance. Plant Cell 6: 1703-1712

Brogue K, Chet I, Holliday M, Cressman R, Biddle P, Knowlton S, Mauvais CJ, Broglie R (1991) Transgenic plants with enhanced resistance to the fungal pathogen Rhizoctonia solani. Science 254: 1194-1197

Buhot N, Douliez JP, Jacquemard A, Marion D, Tran V, Maume BF, Milat ML, Ponchet M, Mikès V, Kader JC, Blein JP (2001) A lipid transfer protein binds to a receptor involved in the control of plant defence responses. FEBS Lett 509: 27-30

Cammue BPA, De Bolle MFC, Terras FRG, Proost P, Van Damme J, Rees SB, Vanderleyden J, Broekeart WF (1992) Analysis of two novel classes of plant antifungal proteins from radish (Raphanus sativus L.) seeds. J Biol Chem 267: 2228-2233

Caruso C, Caporale C, Chilosi G, Vacca F, Bertini L, Magro P, Poerio E, Buonocore V (1996) Structural and antifungal properties of a pathogenesis-related protein from wheat kernel. $J$ Protein Chem 15: 35-44

Douliez JP, Michon T, Elmorjani K, Marion D (2000) Structure, biological and technological functions of lipid transfer proteins and indolines, the major lipid binding proteins from cereal kernels. J Cereal Sci 32: 1-20

Endo S, Demura T, Fukuda H (2001) Inhibition of proteasome activity by the TED4 protein in extracellular space: a novel mechanism for protection of living cells from injury caused by dying cells. Plant Cell Physiol 42: 9-19

Epple P, Apel K, Bohlmann H (1997) Overexpression of an 
endogenous thionin enhances resistance of Arabidopsis against Fusarium oxysporum. Plant Cell 9: 509-520

Evans IJ, Greenland AJ (1998) Transgenic approaches to disease protection: applications of antifungal proteins. Pestic Sci 54: 353-359

Friedrich L, Moyer M, Ward E, Ryals J (1991) Pathogenesis-related protein 4 is structurally homologous to the carboxy-terminal domains of hevein, Win-1 and Win-2. Mol Gen Genet 230: 113-119

García-Olmedo F, Molina A, Segura A, Moreno M (1995) The defensive role of nonspecific lipid-transfer proteins in plants. Trends Microbiol 3: 72-74

Govrin EM, Levine A (2000) The hypersensitive response facilitates plant infection by the necrotrophic pathogen Botrytis cinerea. Curr Biol 10: 751-757

Horsch RB, Fry JE, Hoffma NL, Eichholtz D, Rogers SG, Fraley RT (1985) A simple and general method for transferring genes into plants. Science 227: 1229-1231

Jung HW, Kim W, Hwang BK (2003) Three pathogen-inducible genes encoding lipid transfer protein from pepper are differentially activated by pathogens, abiotic, and environmental stresses. Plant Cell Environ 26: 915-928

Kader JC (1996) Lipid-transfer proteins in plants. Annu Rev Plant Physiol Plant Mol Biol 47: 627-654

Kiba A, Nishihara M, Nakatsuka T, Yamamura S (2007) Pathogenesis-related protein 1 homologue is an antifungal protein in Wasabia japonica leaves and confers resistance to Botrytis cinerea in transgenic tobacco. Plant Biotechnol 24: 247-253

Kiba A, Nishihara M, Tsukatani N, Nakatsuka T, Kato Y, Yamamura $\mathrm{S}$ (2005) A peroxiredoxin Q homolog from gentians is involved in both resistance against fungal disease and oxidative stress. Plant Cell Physiol 46: 1007-1015

Kiba A, Saitoh H, Nishihara M, Omiya K, Yamamura S (2003) C-terminal domain of a hevein-like protein from Wasabia japonica has potent antimicrobial activity. Plant Cell Physiol 44: 296-303

Kuc J (1972) Phytoalexins. Annu Rev Phytopathol 10: 207-232

Lee JY, Min K, Cha H, Shin DH, Hwang KY, Suh SW (1998) Rice non-specific lipid transfer protein: the $1.6 \AA$ crystal structure in the unliganded state reveals a small hydrophobic cavity. $J \mathrm{Mol}$ Biol 276: 437-448

Linthorst HJM, Van Loon LC (1991) Pathogenesis-related proteins of plants. Crit Rev Plant Sci 10: 123-150

Loeza-Angeles H, Sagrero-Cisneros E, Lara-Zárate L, VillagómezGómez E, López-Meza JE, Ochoa-Zarzosa A (2008) Thionin Thi2.1 from Arabidopsis thaliana expressed in endothelial cells shows antibacterial, antifungal and cytotoxic activity. Biotechnol Lett 30: 1713-1719

Marcus JP, Green JL, Goulter KC, Manners JM (1999) A family of antimicrobial peptides is produced by processing of a $7 \mathrm{~S}$ globulin protein in Macadamia integrifolia kernels. Plant J 19: 699-710

Marion D, Bakan B, Elmorjani K (2007) Plant lipid binding proteins: properties and applications. Biotechnol Adv 25: 195-197

Mauch F, Staehelin LA (1989) Functional implications of the subcellular localization of ethylene-induced chitinase and $\beta-1,3$ glucanase in bean leaves. Plant Cell 1: 447-457

Molina A, García-Olmedo F (1997) Enhanced tolerance to bacterial pathogens caused by the transgenic expression of barley lipid transfer protein LTP2. Plant J 12: 669-675

Park CJ, Shin R, Park JM, Lee GJ, You JS, Paek KH (2002) Induction of pepper cDNA encoding a lipid transfer protein during the resistance response to tobacco mosaic virus. Plant Mol Biol 48: 243-254

Sarowar S, Kim YJ, Kim KD, Hwang BK, Ok SH, Shin JS (2009) Overexpression of lipid transfer protein (LTP) genes enhances resistance to plant pathogens and LTP functions in long-distance systemic signaling in tobacco. Plant Cell Rep 28: 419-427

Schägger H, von Jagow G (1987) Tricine-sodium dodecyl sulfatepolyacrylamide gel electrophoresis for the separation of proteins in the range from 1 to $100 \mathrm{kDa}$. Anal Biochem 166: 368-379

Segura A, Moreno M, Madueño F, Molina A, García-Olmedo F (1999) Snakin-1, a peptide from potato that is active against plant pathogens. Mol Plant Microbe Interact 12: 16-23

Shin DH, Lee JY, Hwang KY, Kim KK, Suh SW (1995) Highresolution crystal structure of the non-specific lipid-transfer protein from maize seedlings. Structure 3: 189-199

Simorre JP, Caille A, Marion D, Marion D, Ptak M (1991) Twoand three-dimensional ${ }^{1} \mathrm{H}$ NMR studies of a wheat phospholipid transfer protein: sequential resonance assignments and secondary structure. Biochemistry 30: 11600-11608

Terras FRG, Eggermont K, Kovaleva V, Raikhel NV, Osborn RW, Kester A, Rees SB, Torrekens S, Van Leuven F, Vanderleyden J, Cammue BPA, Broekaert WF (1995) Small cysteine-rich antifungal proteins from radish: their role in host defense. Plant Cell 7: 573-588

Terras FRG, Torrekens S, Van Leuven F, Osborn RW, Vanderleyden J, Cammue BPA, Broekaert WF (1993) A new family of basic cysteine-rich plant antifungal proteins from Brassicaceae species. FEBS Lett 316: 233-240

Thomma BPHJ, Cammue BPA, Thevissen K (2002) Plant defensins. Planta 216: 193-202

Van den Bergh KPB, Rougé P, Proost P, Coosemans J, Krouglova T, Engelborghs Y, Peumans WJ, Van Damme EJM (2004) Synergistic antifungal activity of two chitin-binding proteins from spindle tree (Euonymus europaeus L.). Planta 219: 221-232

van Loon LC, van Strien EA (1990) The families of pathogenesisrelated proteins, their activities, and comparative analysis of PR-1 type proteins. Physiol Mol Plant Pathol 55: 85-97

Vance CP, Kink IK, Sherwood RT (1980) Lignification as a mechanism of disease resistance. Annu Rev Phytopathol 18: 259-288

Zhu B, Chen THH, Li PH (1996) Analysis of late-blight disease resistance and freezing tolerance in transgenic potato plants expressing sense and antisense genes for an osmotin-like protein. Planta 198: 70-77 